\title{
DO VERNACULAR AO ERUDITO: A (RE) CONSTRUÇÃO DA IGREJA MATRIZ DE BATATAIS-SP ${ }^{1}$
}

\author{
Dirceu Piccinato Junior ${ }^{2}$ \\ Ivone Salgado 3
}

DOI: 10.5752/P.2316-1752.2017v24n35p260

\section{Resumo}

O presente trabalho procura traçar um diálogo por meio de questões pertinentes à cultura e à sociedade dos entrantes mineiros, em um primeiro momento, e, depois, dos imigrantes italianos quanto ao processo histórico-construtivo da Igreja Matriz da cidade de Batatais, localizada no nordeste do interior do estado paulista. O edifício religioso foi e ainda permanece, na maior parte das cidades paulistas, como o ponto inicial de formação, ordenamento e expansão urbana. Desse modo, essa edificação reserva em si vestígios, aspectos e contextos singulares para a com-

1. Este artigo toma por base o trabalho que foi apresentado no $3^{\circ}$ Fórum Internacional sobre Patrimônio Arquitetônico Brasil-Portugal que aconteceu em Campinas, São Paulo, no mês de maio de 2016 .

2. Arquiteto e Urbanista pelo Centro Universitário Moura Lacerda, Doutor em Urbanismo pelo Programa de Pós-Graduação em Urbanismo da PUC-Campinas. Arquiteto e Urbanista da Prefeitura Municipal de Sales Oliveira-SP. E-mail: piccinato.jr@gmail.com

3. Arquiteta e Urbanista pela Universidade de São Paulo-USP, Doutora em Urbanismo pelo Institut d'Urbanisme de Paris da Université de Paris XII - Paris-Val-de-Marne. Professora titular da Faculdade de Arquitetura e Urbanismo e do Programa de Pós-Graduação em Urbanismo da PUC-Campinas. E-mail: salgadoivone@uol.com.br 
preensão do modus faciendi da construção. O edifício em destaque se configura como representativo de técnicas, cultura e sociedade local, revelando-se como um "palimpsesto construtivo," ou seja, camadas que revelam momentos e aspectos de um tempo, de um saber, de um lugar. Destarte, objetiva-se elucidar as técnicas construtivas e os estilos arquitetônicos adotados no decorrer de sua construção e reconstrução, assim como relacioná-los com o desenvolvimento sociocultural da região, marcado por dois momentos históricos significativos: o primeiro, quando os migrantes das Minas Gerais ocuparam a região, e o segundo marcado pela colonização italiana no município.

Palavras-chave: Entrantes mineiros. Imigração italiana. Igreja Matriz. 
GENUINE OF THE ERUDITE: THE (RE)CON-
STRUCTION OFTHE CHURCH OF BATATAIS-SP

\section{Abstract}

This paper attempts a dialogue through issues pertaining to culture and society, at first, incoming miners and then Italian immigrants about the historical process of constructive mother church of Batatais, located in the northeastern interior of São Paulo state. The religious building was and still remains, in most cities of São Paulo, as the starting point for training, planning and urban expansion. In this sense, this building reserves itself traces, unique aspects and contexts to understand the modus faciendi construction. For the following discussion, the construction in question is configured as one representative of techniques, cultural and social site; performing a "constructive palimpsesto", or as layers that tend to reveal aspects of the moments and time, a knowledge of a place. Thus, the objective is to elucidate the construction techniques and architectural styles adopted during its construction and reconstruction, as well as relate them to the cultural development of the region occurred in two historical dimensions: the first marked by the migrant from Minas Gerais and the second by the Italian colonization in the city.
LA LENGUA VERNÁCULA PARA EL INVESTIGADOR: LA (RE)CONSTRUCCIÓN DE LA IGLESIA MADRE DE BATATAIS-SP

\section{Resumen}

Este documento trata de un diálogo a través de preguntas relacionadas con la cultura y la sociedad de los mineros participantes, en un primer momento, y luego de inmigrantes italianos y et proceso de construcción histórica de la Iglesia en la ciudad de Batatais, situada en el noreste del interior el estado de Sao Paulo. El edificio religioso ha sido y sigue siendo, en la mayoría de las ciudades de Sao Paulo, como punto de partida para la formación, la planificación y la expansión urbana. En este sentido, esta reserva edificio en sí sigue siendo, aspectos y contextos para entender el modus construcción faciendi únicas. Lo más destacado en la construcción aparece como técnicas de representación, la cultura local y-la sociedad, que se revela como un "palimpsesto constructiva", es decir capas que revelan momentos y aspectos de un tiempo, de conocimientos, de un Fugar. Por lo tanto, el objetivo es dilucidar las técnicas de construcción y estilos arquitectónicos adoptados durante su construcción y reconstrucción, así como relacionarlos con el desarrollo socio-cultural de la región, marcada por dos momentos históricos importantes: la primera, cuando los migrantes de Minas Gerais que ocupaban la región, y la segunda marcada por la colonización italiana en la ciudad.

Palabras-claves: Mineros entrantes. La inmigración italiana. Iglesia Madre.
Keywords: Incoming miners. Italian immigration. Church.

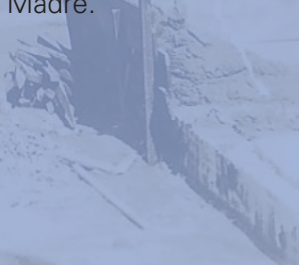




\section{Introdução}

De maneira geral, a igreja e a praça definiam o espaço urbano primário de muitas localidades brasileiras no período colonial, o que se conservou na maioria das novas cidades fundadas durante o Império, quando essa centralidade muitas vezes é disputada com a estação ferroviária. As edificações seculares dificilmente se destacavam em importância em relação à casa de oração. No interior dessa última, reuniam-se os fiéis e, ao redor de seu adro, perfilavam-se casas, vendas e, dependendo do status da localidade, isto é, freguesia ou vila, a casa de câmara e cadeia. O largo, pátio, circunscritos depois na República pela praça da matriz, que era uma área generosa destinada à saída e retorno das procissões, à encenação dos autos de fé e serviam conjuntamente como ponto de referência aos visitantes e aos membros da comunidade. Tal regra foi responsável pelas "características gerais apontadas para a nossa cidade tradicional" (MARX, 1980, p. 54).

Quando a capela de uma localidade almejava se tornar freguesia ${ }^{4}$, a ermida originária era elevada à condição de

\footnotetext{
4. Segundo a pesquisadora Maria Fernanda Derntl, uma capela, além da própria construção, deveria ter um patrimônio fundiário capaz de assegurar uma renda mínima para as despesas anuais. A elevação de uma capela à condição de freguesia costumava levar em consideração critérios de ordem econômica, demográfica, política e territorial; nesse status de freguesia, o território deveria ser necessariamente demarcado (DERNTL, 2010, p. 66).
} 
igreja matriz. Isso significava que a antiga capela passaria a ser objeto de sucessivas reformas, visando a mais solidez, condizente com a nova categoria alcançada. Desse modo, a igreja foi e continua a ser, na maior parte das cidades paulistas, a representação de um conjunto de ações importantes para se compreender o processo de formação urbana e, consequentemente, o método construtivo de uma edificação, de uma cultura, de um saber fazer no campo da arquitetura e da técnica construtiva.

A partir da intenção dos moradores locais até o momento em que efetivamente era edificada a ermida, observa-se uma reunião de ideias, trabalhos e vivências que possibilitaram a muitas dessas construções religiosas traduzirem uma realidade socioespacial. Isso significa a possibilidade de identificar "camadas construtivas" que revelem uma identidade nacional, regional e até mesmo local.

Consagrada a Bom Jesus da Cana Verde quando de sua fundação, a Igreja Matriz de Batatais cristaliza os valores socioculturais nos seus desdobramentos construtivos. Portanto, considerando a história de uma sociedade como história da construção, a edificação em análise fundamenta-se em um recorte temporal que contempla dois momentos ou duas dimensões históricas muito bem definidas e que traduzem em barro, tijolo e cimento soluções técnicas e estilísticas adotadas pela comunidade dessa localidade du- 
rante parte dos séculos XIX e XX.

Em fins do século XVIII, muitos dos moradores da capitania de Minas Gerais, observando a exaustão das minas de ouro e pedras, buscaram como alternativa econômica para sua sobrevivência a produção agrícola, a pecuária e a comercialização de seus derivados. Tal ensejo promoveu a afluência de mineiros para a região nordeste da capitania paulista em busca de novas oportunidades. Esse movimento migratório ficou registrado nos documentos da época como uma ação dos "entrantes mineiros" 5 . Do ano de 1804 a 1824, o número de entrantes nessa região passava de 680 migrantes. No ano de 1804, o número de mineiros representava $24,7 \%$ em relação a $71,7 \%$ de área desocupada e a 4,6\% de outros migrantes. Nos anos seguintes, observa-se um aumento significativo, especialmente em decorrência das novas formações urbanas ${ }^{6}$ e da oportunidade de se ocupar terras incultas. Em 1824, chega-se à porcentagem de 75\% de mineiros, 3\% de outros contingentes de migrantes e 22\% de área ainda desocupada (CHIACHIRI FILHO, 1986,

\footnotetext{
5. Quem descreve com propriedade os fatos e conceitos acerca dos entrantes mineiros é Lucila Reis Brioschi em sua tese de doutoramento, fundamentada numa pesquisa "documental sobre as origens e o montante dos fluxos migratórios para a região" (BRIOS$\mathrm{CHI}, 1995$, p. 13) nordeste paulista, antigo sertão do rio Pardo no século XVIII e início do século XIX.

6. No ano de 1805 é fundada a Freguesia de Nossa Senhora da Conceição da Franca, atual cidade de Franca; em 1815 são fundadas a Freguesia de Nosso Senhor Bom Jesus da Cana Verde dos Batataes, hoje Batatais, e a Freguesia de Nossa Senhora das Dores de Casa Branca, atual cidade de Casa Branca (PICCINATO JUNIOR, 2012, p. 97-99).
} 
p. 141). Esses valores revelam a importância dessa corrente migratória mineira nessa parte do território paulista.

A maior parte das cidades fundadas nessa região é resultado de ações desses entrantes; Batatais figura entre elas. A então Freguesia de Nosso Senhor Bom Jesus da Cana Verde dos Batataes (segundo a grafia da época) possuía, ainda em 1815, segundo palavras do Padre Bento Jozé Pereira, uma "tosca Caza de Oração, que interinamente vai servindo"7, evidenciando a necessidade de uma nova construção religiosa que manifestasse o caráter da freguesia. Esse contexto representa a primeira dimensão histórica da Matriz, ou seja, a filiação de um vocabulário arquitetônico colonial, com o interior em talha barroca, trazido pelos próprios mineiros quando da primeira solução construtiva empregada na obra.

A década de 1880 foi a de maior vulto no desenvolvimento da malha ferroviária no estado de São Paulo em função da grande produção cafeeira. O rápido crescimento das plantações de café demandou uma mão de obra mais abundante: uma política de imigração foi adotada pelos cafeicultores. Os principais grupos de imigrantes que entraram no estado foram os italianos, seguidos por portugueses, espanhóis, japoneses e, em menor escala, os alemães e austríacos.

7. Esse registro que revela o estado da Capela está no Livro Tombo $n^{\circ} 1$ da Igreja Matriz de Batatais, s/n. 
Quando desembarcaram no Brasil, os imigrantes não buscaram oportunidades de trabalho somente nas lavouras cafeeiras, mas, também, nas cidades.

Em Batatais, parte da colônia italiana, quando ali chegou, por volta da década de 1890, afluiu às fazendas de café; outra parte integrou-se à cidade, passando a se dedicar ao comércio, ao artesanato, às manufaturas e aos pequenos serviços. Todavia, pode-se ressaltar que os imigrantes italianos não mudaram apenas a economia local com o trabaIho nas lavouras, nos novos comércios e com prestações de serviços; eles reconstruíram o urbano e difundiram seus conhecimentos arquitetônicos e técnicos construtivos, pois muitos que ali se estabeleceram tinham formações eruditas nas áreas da construção, engenharia e arquitetura. Foram os mestres construtores italianos os responsáveis por fomentar o segundo momento histórico, empregando seus conhecimentos técnicos e sua erudição estilística nas reconstruções da Igreja Matriz.

\section{Os entrantes mineiros e a construção da Igreja de Nosso Senhor Bom Jesus da Cana Verde}

Em Minas Gerais, a mineração do século XVIII foi a atividade econômica de maior relevância. No entanto, essa mesma atividade favoreceu o desenvolvimento de um importante setor produtivo formado em função de um mercado 
consumidor: a criação de gado e o aproveitamento do leite. Foi justamente em razão das novas atividades econômicas que muitos mineiros ocuparam vastas extensões de terras no território paulista, entre elas a do Sertão do Rio Pardo (BRIOSCHI, 1995, p. 6-35).

Quando os entrantes chegaram à região, não eram apenas homens aventureiros; a maioria era formada, na verdade, por conjuntos de famílias nucleares. "Ao agruparem a população segundo os domicílios, os censos identificavam como seus integrantes pai, mãe e filhos, na grande maioria dos casos" (BRIOSCHI, 1995, p. 171). Segundo dados quantitativos, em 1801, havia apenas 2 casais mineiros na região; em 1819, esse número passou para 19 casais; em 1817, passa para 24 e, em 1825, chega a 64. Quanto à estrutura, casal mais os filhos, os números indicam o seguinte: no ano de 1801, havia 24; em 1807, esse número se elevou para 131; em 1817, foi para 169 e, no ano de 1825, houve um significativo aumento, alcançando o número de $292 \mathrm{ca-}$ sais mais os filhos (PICCINATO JUNIOR, 2012, p. 79).

Portanto, seja pela extração mineral, seja pela expansão agropecuária, a região em destaque ofereceu condições para grupos familiares inteiros, que procuravam, no manejo do solo e na criação, novas perspectivas de sobrevivência econômica. A chegada das famílias mineiras promoveu mudanças sociais, econômicas e políticas. Pode-se citar, entre 
essas significativas mudanças, o processo de formações urbanas, com destaque para Batatais.

O primitivo povoado teve sua gênese em um terreno doado por Manuel Bernardes do Nascimento e Antonio José Dias, procedentes das Minas, de onde veio a imagem do Senhor Bom Jesus. Em função de disputas e interesses particulares, o povoado foi deslocado para uma área denominada "Campo Lindo das Araras." Essas terras foram doadas por Germano Alves Moreira e sua esposa, Anna Luiza, em 15 de março de 18238, quando "aí é que tomou a denominação de Senhor Bom Jesus da Cana Verde de Batatais" (LElTE, 1961, p. 179).

Quando de sua fundação, Batatais, assim como a maioria das povoações no período colonial, cumpriu o que as constituições primeiras do arcebispado da Bahia determinavam no que se refere à questão da construção do edifício religioso em local elevado do patrimônio, junto a um largo ou até mesmo no centro dele. As constituições estabeleciam ainda que a ermida deveria ser construída em lugar decente, alto, livre de umidade, distante de lugares sujos e com espaço suficiente ao seu redor para as celebrações religiosas. “Tais termos eram sempre citados na autorização conferida

8. Essa data é um tanto divergente, pois alguns estudos locais datam o dia 10 de agosto de 1822; todavia o Livro Tombo ${ }^{\circ} 1$ da Igreja Matriz de Batatais registra a data de 15 de março de 1823. 
pelo bispo" (GHIRARDELLO, 2010, p. 136), na determinação para a construção do edifício religioso.

De acordo com Ghirardello (2010), em seus estudos recentes, a construção de uma capela mineira seguia "os modelos tradicionais", ou seja, apresentava um frontão triangular com a presença de um óculo, janelas no coro, porta de entrada, telhado em duas águas, esteios de madeira, uma torre sineira fora do corpo principal do edifício e construída em taipa de mão. Sobre a planta, deveria apresentar uma nave principal, a capela-mor, sacristia e algumas, dependendo do lugar, naves laterais dotadas de telhados um pouco mais baixos. Em suma, a capela "representava o primeiro esforço coletivo" (GHIRARDELLO, 2010, p. 135) da localidade na consolidação do domínio territorial.

Ao analisar a primeira solução adotada na Igreja Matriz de Nosso Senhor Bom Jesus da Cana Verde de Batataes (Figura 1), observam-se algumas diferenças em relação ao "modelo tradicional," possivelmente por se analisar uma matriz e não uma capela. Construída pelos entrantes e inaugurada em 18 de maio de 1838, identificam-se algumas características similares ao que foi descrito: frontão triangular, o óculo, o uso de materiais vernaculares (barro e madeira) da região e o telhado em duas águas; entretanto, não há uma torre sineira, mas duas, e elas estão juntas ao corpo da construção, similarmente a outros exemplares encontra- 
dos na região.

Tão logo inaugurada, os cidadãos e a Câmara Municipal, a partir de 1840, começaram a trocar correspondência com o Presidente da Província de São Paulo, solicitando verbas para dar continuidade às obras:

A Igreja Matriz não vai ser de novo começada. Ella acha-se coberta; a Capella Mor já esta feixada é nella se celébrão os Officios Divinos: uma sacristia e o correspondente consistório estão feitos, e é ahi que tem lugar as Sessões do Jury. (...) Falta feixar-se com paredes, e assoalhar o corpo da Igreja, fazer-se os corredores que acompanhão pelo lado de fora para comodidade e maior segurança do edifício, falta ultimar-se uma Sacristia, e o consistório que lhe corresponde, fazer um retábulo ainda que ligeiro, e mais algumas obras na Capella mor, e $p^{a}$ tudo isto já não é possível contar-se com os dinheiros dos fieis (DUTRA, 1993, p. 31-32).

No ano de 1852, o Presidente da Câmara Municipal responde ao Governo da Província dando notícias de a Igreja estar prestes a ser concluída, conforme apontam as Atas da Câmara de março de 1852. Com a conclusão das obras, a Matriz sofreu algumas modificações (Figura 2), o frontispício ganhou novas aberturas, assim como as torres; estas últimas ainda foram reformadas, pois ganharam melhores acabamentos. O corpo da igreja foi prolongado na parte posterior devido à construção da sacristia. 


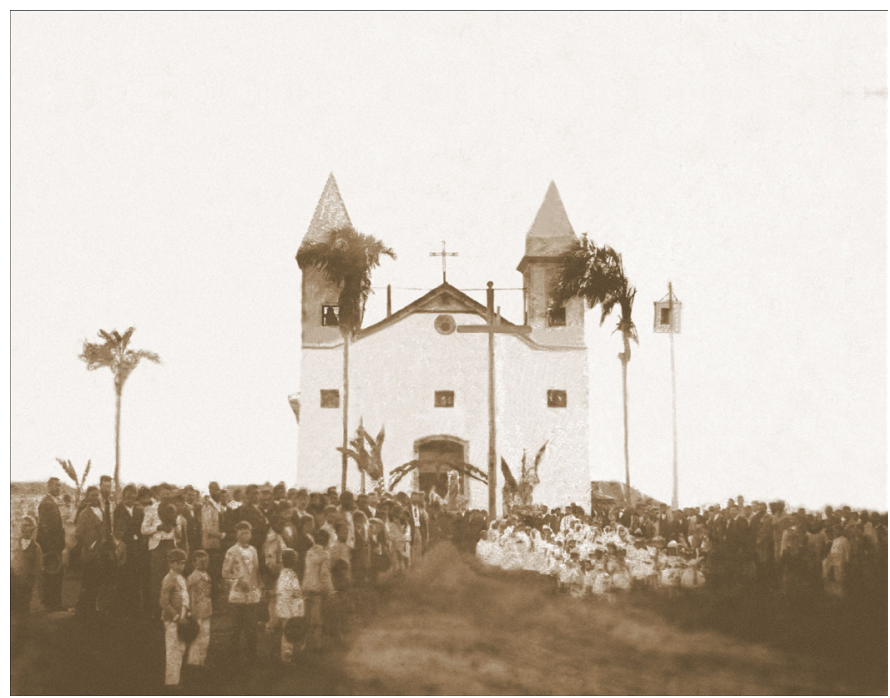

Figura 1 | A Igreja Matriz de Batatais construída pelos entrantes mineiros em 1838 antes da reforma em 1860. Fonte: Acervo da Igreja Matriz de Batatais. 


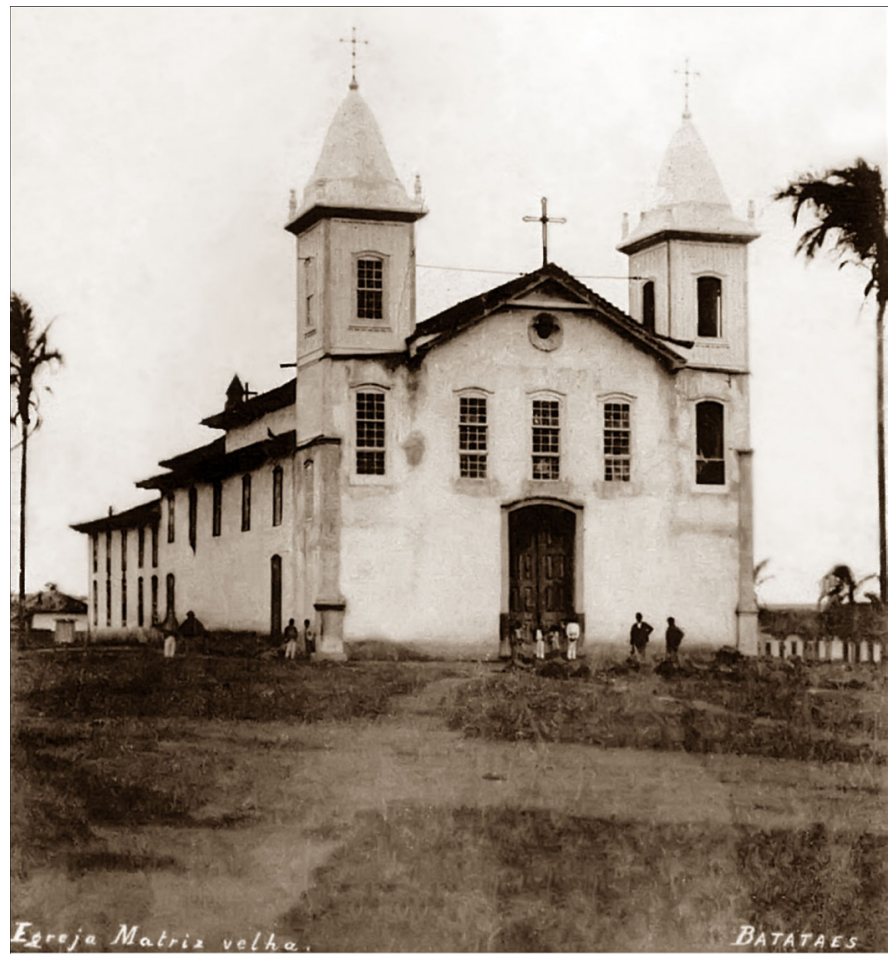

Figura 2 | A Igreja Matriz de Batatais depois da reforma em 1860. Fonte: Acervo da Igreja Matriz de Batatais. 
Sobre as técnicas adotadas na construção do edifício, há alguns relatos pertinentes. Um deles é o de Jean de Frans, memorialista local que assim descreve a Igreja naquele momento: era a "Matriz, enorme, pesada, com duas torres e com as grossas paredes de adobes, ficava bem no centro do respectivo largo." Outro relato é de José Braga Morato, antigo coletor de impostos da Prefeitura de Batatais, nascido no ano de 1903, que assim a descreveu: "a Igreja Matriz era construída de adobos e o teto era sustentado por oito colunas de aroeira lavrada, de mais ou menos dez metros de altura." (DUTRA, 1993, p. 33).

A construção em adobe foi muito comum em Minas Gerais e Goiás. Essa técnica utiliza-se do barro e de uma determinada quantidade de areia como matérias-primas. Grosso modo, o barro deve ser sovado e moldado em formas de madeira, em seguida os tijolos, ainda nas formas, devem ser levados à sombra para o decurso da secagem. Essa fase pode durar em torno de 2 a 3 dias em área descoberta e aproximadamente 30 dias em ambiente coberto. Quanto mais fino e menor for o adobe, mais rápida é a cura; por se tratar de um processo físico, o tempo da perda de água é determinado pela temperatura, umidade, ventilação e espessura. As paredes em tijolos de adobe são construídas conforme qualquer parede de alvenaria de tijolo comum. Destarte, a fundação é feita usualmente em sapata corrida de pedra para isolar a parede da umidade do solo. Os 
acabamentos externos, como chapisco e pintura, são empregados para proteger a estrutura das intempéries (TAGOMORI; CAVALLARO, 2011).

O conjunto de elementos do altar-mor foi composto em um vocabulário barroco (Figura 3) e teve sua origem durante as obras de conclusão da construção do templo pelos mineiros. Permaneceu na segunda solução construtiva e estilística dos imigrantes italianos e só foi alterado quando da sua transferência para outra casa de oração da cidade em função da demolição do teto da Matriz para dar lugar à cúpula central, durante a sua terceira e última reforma. Embora tenha retornado para a Igreja Matriz nessa sua última reforma, acabou sendo destruído e substituído pelo políptico do pintor Cândido Portinari.

Construído em talha, trabalho escultórico por entalhe feito em uma superfície de madeira, o altar-mor da Matriz filiava-se ao estilo de decoração barroca, muito difundido nas obras religiosas do século XVIII em Minas Gerais. Esse tipo de trabalho aparece usualmente nos altares, tanto nos laterais como no altar-mor, marcado pelo arco cruzeiro, tetos e janelas, recobrindo praticamente o interior do templo. Nesse tipo de ornamentação, é comum encontrar as temáticas florais, figuras de anjos, linhas sinuosas e espiraladas, que, de certo modo, são "formas que sugerem movimento e quebram a monotonia das linhas retas que geometrizam o 
espaço" (SANTOS, 2007, p. 208).

O movimento migratório dos entrantes mineiros no território paulista não promoveu apenas mudanças econômicas, sociais e políticas no novo território, mas, também, a difusão de um saber construtivo e de uma linguagem artística das Gerais.

\section{A colonização italiana em Batatais e as recons- truções da Igreja Matriz}

Os italianos formaram a maioria do contingente imigratório para o trabalho nas lavouras de café. A política de imigração implantada no Brasil a partir da segunda metade do século XIX dava preferência à vinda de agricultores acompanhados de suas famílias, porque estavam mais propensos a se fixarem nas fazendas, ao contrário daqueles que vinham sozinhos, os quais poderiam desistir facilmente da lida. Entre os anos de 1880 e 1900, a cidade de "São Paulo recebeu mais de 500 mil italianos" (FREITAS, 1999, p. 45) que, ali chegando, dirigiam-se às lavouras de café no interior do estado ou às indústrias emergentes na própria capital. A crise pela qual a Itália passava na época motivou os italianos a buscarem o Brasil como alternativa. 


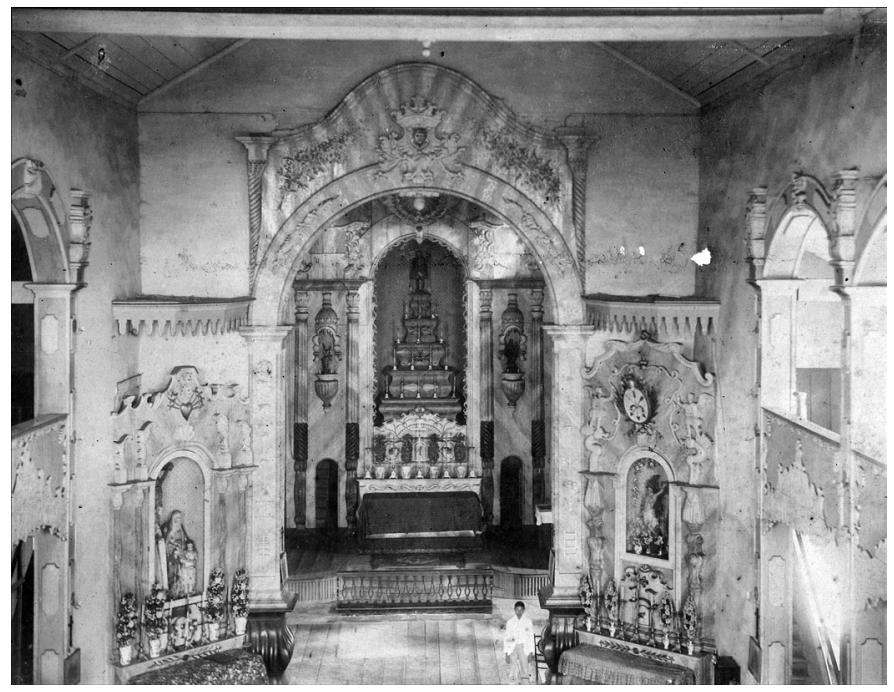

Figura 3 | Altar-mor da Igreja Matriz de Batatais, s/d.

Fonte: Museu Histórico Washington Luís - Batatais (Acervo J. A. Fernandes). 
Freitas (1999), comentando a presença dos italianos na capital paulista, destaca que "o traço mais saliente da cidade é sua italianidade". Em muitas das cidades paulistas, ouvia-se falar muito mais italiano do que português, como ocorreu com São Paulo. Nas ruas, praças e comércio se fundiam os dialetos venezianos e toscanos. Inúmeras escolas e sociedades de música e pintura italianas foram criadas. Vinhos, pães, tecidos, livros, entre outros objetos eram de origem italiana (FREITAS, 1999, p. 46).

Uma vez estabelecida a colônia italiana nas cidades, urbanizar tornou-se sinônimo de realizar obras que resultassem em melhores condições de vida para uma cidade. A cultura e o conhecimento de muitos que aqui desembarcaram e passaram a atuar foram preponderantes na reconfiguração do tecido urbano: abrir ruas, alinhar aquelas que já existiam, construir novas praças e jardins, iluminar o espaço público, melhorar o atendimento em saúde, o ensino, canalizar água e esgoto, implementar a coleta do lixo, construir e reformar edifícios foram alguns dos aspectos mais significativos dessa urbanização marcada pela presença dos imigrantes.

O movimento perpetrado pelos italianos não se resumiu apenas aos trabalhos na cafeicultura, no comércio e em serviços; eles atuaram significativamente no processo de reestruturação das cidades, situação facilmente observada em Batatais. 
A colônia italiana instalada no município batataense foi se tornando expressiva no início do século XX. Na primeira década dos anos de 1900, residiam na cidade aproximadamente 3.500 italianos natos e cerca de mil filhos de italianos. A grande maioria trabalhava na lavoura, mas uma parcela dedicava-se aos setores de serviços e indústrias. Eles possuíam em torno de 112 propriedades agrícolas com aproximadamente 4.569 alqueires. $O$ grande interesse por parte desses imigrantes em relação à cidade de Batatais pode ser revelado pela sua participação na construção civil como mão de obra especializada. Foi o caso de Guilherme Rosada, italiano nascido na cidade de Rovigo, em $1^{\circ}$ de fevereiro de 1877, responsável pela alteração do "estilo colonial da Igreja Matriz de Batatais em estilo gótico" (FERNANDES, 2004, p. 33). No ano de 1895, o Cônego Joaquim Alves e a Comissão composta por importantes homens da cidade, como os coronéis Manoel Theodolino do Carmo, Antônio Rosa, Francisco Prudente, entre outros, se uniram para a reconstrução da Matriz.

As obras de reforma se estenderam por anos, como aponta a iconografia de época: o primeiro momento dessa reforma data de 1911 (Figura 4), quando se pode observar a mudança estilística da fachada frontal, que adquire um estilo neogótico. Em 1928, essa reforma está sendo concluída na fachada posterior do edifício (Figura 5). Nessa data, um canteiro de obras já estava ali instalado, pois um novo projeto 
já estava em vias de ser implantado.

A proposta de Rosado tinha como linguagem estética o neogótico, estabelecendo junto à edificação um verticalismo comedido, muito em função do corpo central construído pelos entrantes, que acabou permanecendo. O uso de arcos ogivais para dividir o peso, grandes aberturas, o uso dos vitrais para proporcionar maior amplitude para a iluminação interior e o portal principal com traços ogivais foram utilizados nesse momento da reforma; essas características são particulares do vocabulário gótico. Entretanto a característica singular da arquitetura gótica empregada nessa reforma foi a abertura em forma de rosácea no alto da porta central. O altar-mor permaneceu o mesmo em sua estrutura e suas características, todavia apresentou algumas mudanças pontuais na disposição dos seus elementos. Esse segundo aspecto adotado na Igreja Matriz ficou restrito apenas às fachadas frontal e posterior do edifício, desenvolvido sob a técnica construtiva de alvenaria. Como se pôde observar, as condições sociais, materiais e técnicas da localidade não possibilitaram grandes mudanças segundo o modelo da arquitetura eclética em difusão no século XIX. 


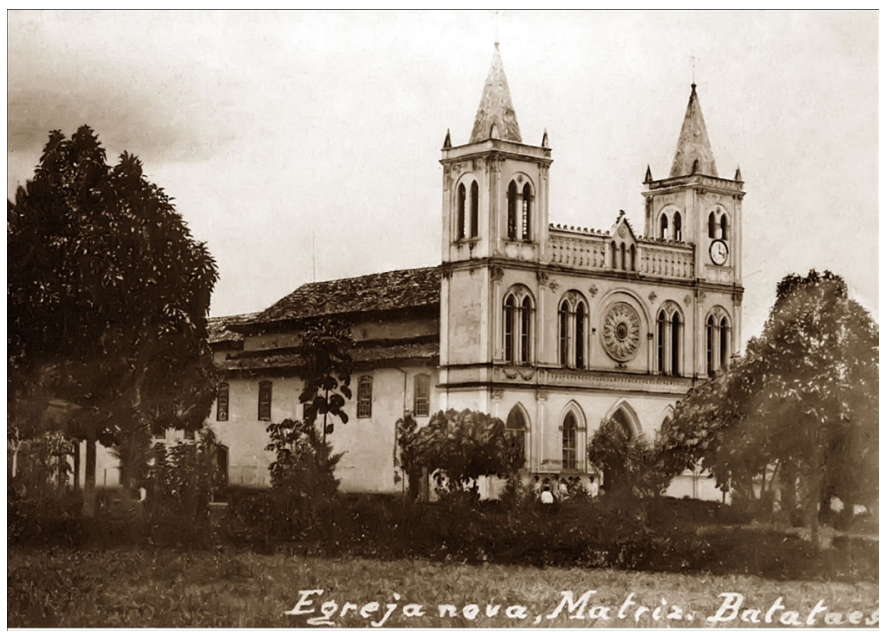




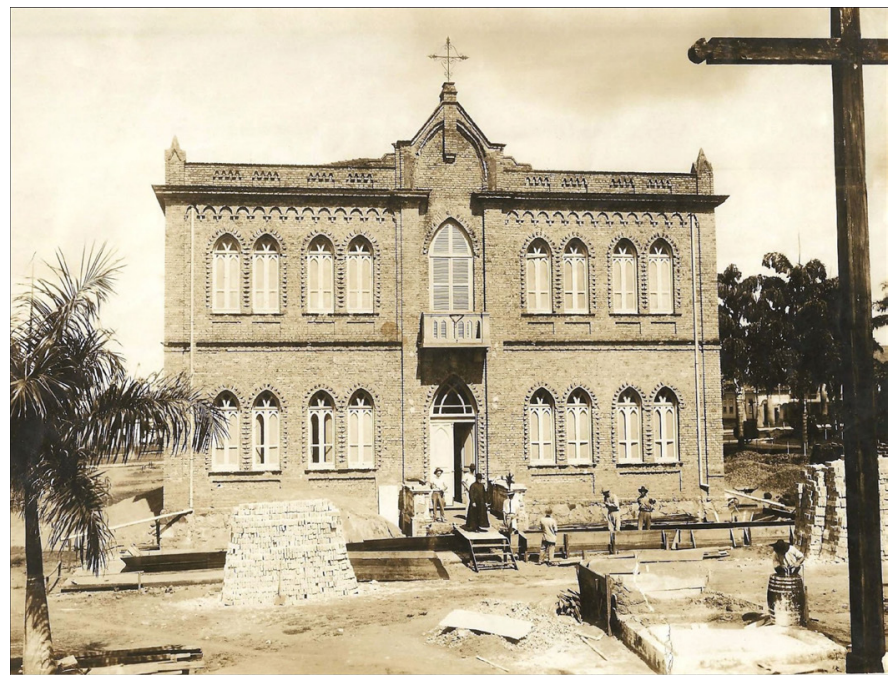

Figura 5 | O Gótico tardio da Igreja Matriz de Batatais, 1928.

Fonte: Acervo da Igreja Matriz de Batatais. 
Essa releitura eclética das características góticas não era um acontecimento isolado na arquitetura paulista. Pode-se identificar esse "movimento" na cidade de São Paulo, por exemplo, na construção da Capela da Santa Casa de Misericórdia, edifício idealizado por Luigi Pucci, italiano radicado no Brasil que se dedicava à construção. Outro exemplo que aconteceu em uma escala temporal muito próxima à de Batatais foi a edificação da Catedral Metropolitana de São Paulo, com projeto do arquiteto alemão Maximilian Emil Hehl, cujas obras começaram em 1913. Ela foi construída em estilo eclético, numa linguagem neogótica.

Nas primeiras décadas do século XX, novos construtores chegaram a Batatais; entre eles destacam-se: Ângelo Rossini, mestre de obras, que veio da Itália a convite da ordem salesiana para construir uma escola agrícola e formou vários pedreiros locais; Fausto Bellini Degani, também mestre de obras, pedreiro, músico e escultor; Júlio E. Latini, "engenheiro architecto"; Carlos Zamboni, engenheiro civil formado pela Universidade de Milão, tinha profundos conhecimentos de arquitetura. Esses e outros trabalharam na transformação da paisagem urbana da cidade de Batatais. Colocaram em prática o conhecimento, a cultura e as técnicas vivenciadas em seu país de origem. Em síntese, promoveram a circulação das ideias arquitetônicas e urbanas.

No ano de 1926, a Matriz permanecia inacabada no centro 
da cidade, gerando um descontentamento entre os cidadãos. Nesse momento, a imprensa local passou a desempenhar um importante papel, veiculando o descontentamento acerca do estado da igreja:

Quem é que olhando para a nossa Igreja Matriz, não se manifeste pela conclusão das obras, já tão tardia? Por certo que ninguém, tanto mais porque já faz alguns annos que reconstruída uma parte, incompleta externamente, na outra ainda não se pôz mão (GAZETA DE BATATAIS, 1926a).

O principal responsável pelas obras de reconstrução, Monsenhor Joaquim Alves Ferreira ${ }^{9}$, enviou uma carta ao jornal local, relatando que realmente era importante a reconstrução ou construção de um edifício que representasse a nova ordem social, econômica, política e religiosa daquele momento. Porém esclareceu que a igreja estava naquelas condições devido à situação financeira e solicitou a formação de uma comissão popular para angariar donativos para a obra. Junto a essa carta, o Monsenhor envia um cartão postal do "plano primitivo modificado"10 em função das dificuldades múltiplas que enfrentavam naquele momento:

9. Figura de destaque, nasceu em 27 de outubro de 1880; batataense de nascença, foi ordenado padre aos 24 anos, doutorou-se em Roma e faleceu no ano de 1946 na cidade natal.

10. Esse cartão postal revela o desejo de construção de uma igreja em estilo neogótico, pois apresentava uma volumetria "irregular e variada, contendo uma potente torre terminada em agulha, onde já se procurava a escala monumental para o mais importante edifício da cidade" (Dutra, 1993, 376). 
A deficiencia de operários e de materiaes, a falta de água que tanto se fazia sentir naquella epocha, juntamente com a desorientação geral produzida pela conflagração européia, que tanto accentuou na vida do paiz, e principalmente a falta de recursos pecuniários, tudo isso influenciou para um estado de pânico, e consequente paralysação dos trabalhos (GAZETA DE BATATAIS, 1926b). ${ }^{11}$

O "plano primitivo modificado" foi abandonado e as obras de reconstrução da Igreja foram paralisadas. Novamente o Monsenhor vem a público em texto do jornal local, em janeiro de 1927, justificar o motivo da paralisação que, segundo ele: "a interrupção dos trabalhos foi exclusivamente devido à falta de esthetica que se estava notando nas obras e não queria dar a responsabilidade de seu nome a um templo que estava em desacordo com o progresso de Batataes" (GAZETA DE BATATAIS, 1927a) ${ }^{12}$.

Uma comissão então foi constituída para angariar fundos para a realização das obras. Contudo algumas questões ainda foram levadas a público: fazer uma igreja nova ou dar continuidade à reforma? A solução foi conciliatória: a antiga estrutura de alvenaria seria reaproveitada (DUTRA, 1993,

\footnotetext{
11. Essa citação é parte de uma carta escrita pelo Monsenhor Joaquim Alves Ferreira, principal responsável pelas obras, endereçada ao jornal a Gazeta de Batatais, em 1 de março de 1926, comentando o motivo da paralisação da reforma.

12. Trecho de outra correspondência do Monsenhor endereçada ao jornal a Gazeta de Batatais, publicada em 21 de janeiro de 1927.
} 
p. 377). Assim sendo, para idealizar o edifício religioso que estivesse à altura do progresso, de uma renovada arquitetura e da importância conquistada por Batatais nessa região, foram contratados os serviços do "engenheiro architecto" Júlio E. Latini. O primeiro registro de sua presença na cidade foi noticiado na Gazeta de Batataes em setembro de 1927: "Acha-se nesta cidade, a serviço, e aqui pretende passar uma temporada o Sr. Dr. Latini, hábil engenheiro constructor, que acaba de assinar importantes contractos de ricas construcções em Batatais" (GAZETA DE BATATAIS, 1927b) ${ }^{13}$.

No projeto desenvolvido por Latini para a Igreja Matriz de Batatais, pode-se observar uma diversa manifestação do ecletismo, nessa versão claramente filiado ao renascimento italiano, como assinalam as figuras 6 e 7, pois o profissional utiliza-se da planta em cruz, traço característico do renascimento.

A planta só não foi desenvolvida simetricamente em função do reaproveitamento de parte da construção, particularmente a parte posterior, que já havia sido reconstruída. No restante do projeto, Latini aumentou as dimensões, "inclusive com a adição da torre central, onde dispôs o relógio" (DUTRA, 1993, p. 378). Latini envolveu a parte pos-

13. Além da Igreja Matriz, o profissional foi responsável pelo Palacete do Monsenhor Joaquim Alves e as reformas do Ginásio São José. 
terior, já acabada, com paredes novas e a destinou à área administrativa da Igreja (Figuras 8 e 9). As obras dessa (re) construção da Igreja se iniciaram em janeiro de 1928 e só terminaram em março 1953.

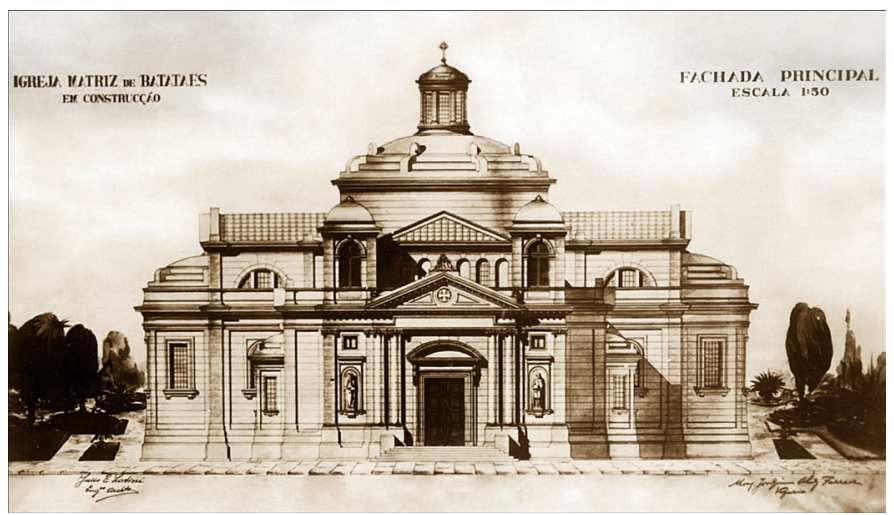

Figura 6 | Projeto para Igreja Matriz de Batatais, por Júlio E. Latini, 1927.

Fonte: Acervo da Igreja Matriz de Batatais 


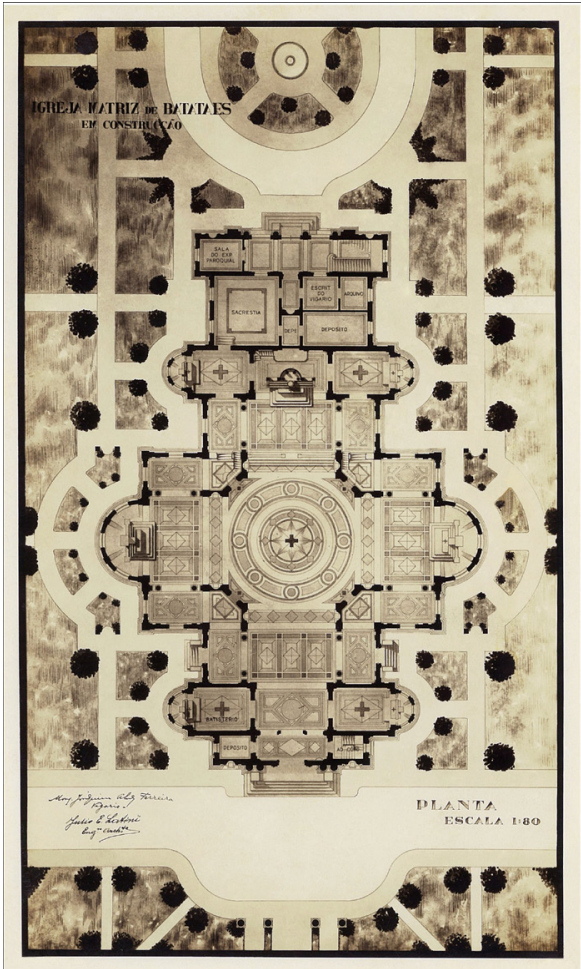

Figura 7 | Projeto para Igreja Matriz de Batatais, por Júlio E. Latini, 1927. Fonte: Acervo da Igreja Matriz de Batatais 


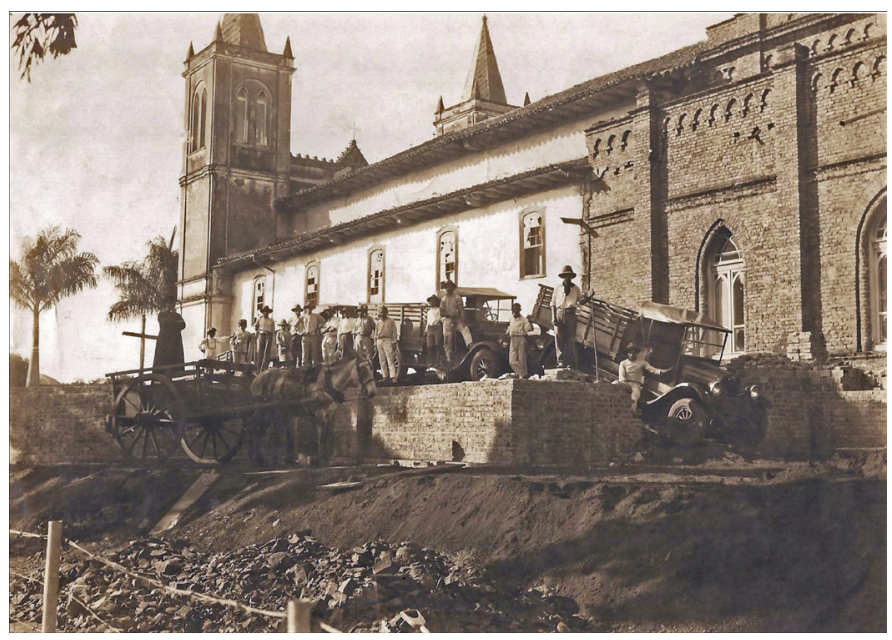

Figura 8|A (re)construção da Igreja Matriz de Batatais, 1928.

Fonte: Acervo da Igreja Matriz de Batatais. 


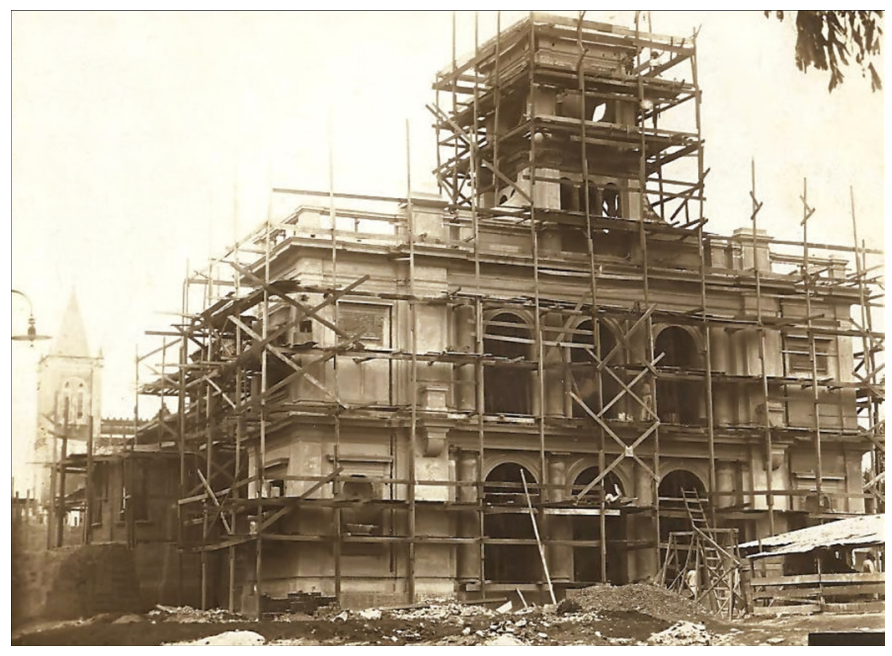

Figura 9 |A (re)construção da Igreja Matriz de Batatais, 1928.

Fonte: Acervo da Igreja Matriz de Batatais. 
O projeto foi concebido buscando desenvolver um trabaIho em volumes geométricos que se interpenetrassem, de maneira que o centro foi ocupado pela cúpula. Na parte central, o bloco desenvolveu-se em cruz, pontuando nessa mesma área do projeto o duomo, em uma altura maior do que as demais volumetrias externas. Na visão da fachada frontal, nota-se uma acentuada simetria ocasionada pelos volumes geométricos. Possivelmente o aspecto mais interessante do projeto foi a solução dada à cúpula: "um amplo volume cilíndrico compacto, sem aberturas, marcado por linhas horizontais, como de resto, todo o edifício" (DUTRA, 1993, p. 382).

No ano de 1928, o engenheiro italiano Carlos Zamboni já estava em Batatais acompanhando as obras de Latini. Zamboni nasceu em Brescia, cidade italiana, porém graduou-se em engenharia civil em Milão. No ano de 1927, veio para o Brasil e passou a residir em Santos. Ao tomar conhecimento de um anúncio de jornal santista, no qual solicitava-se um engenheiro para as obras batataenses, Zamboni deixou Santos e partiu para Batatais, onde foi contratado (DUTRA, 1993, p. 383). 


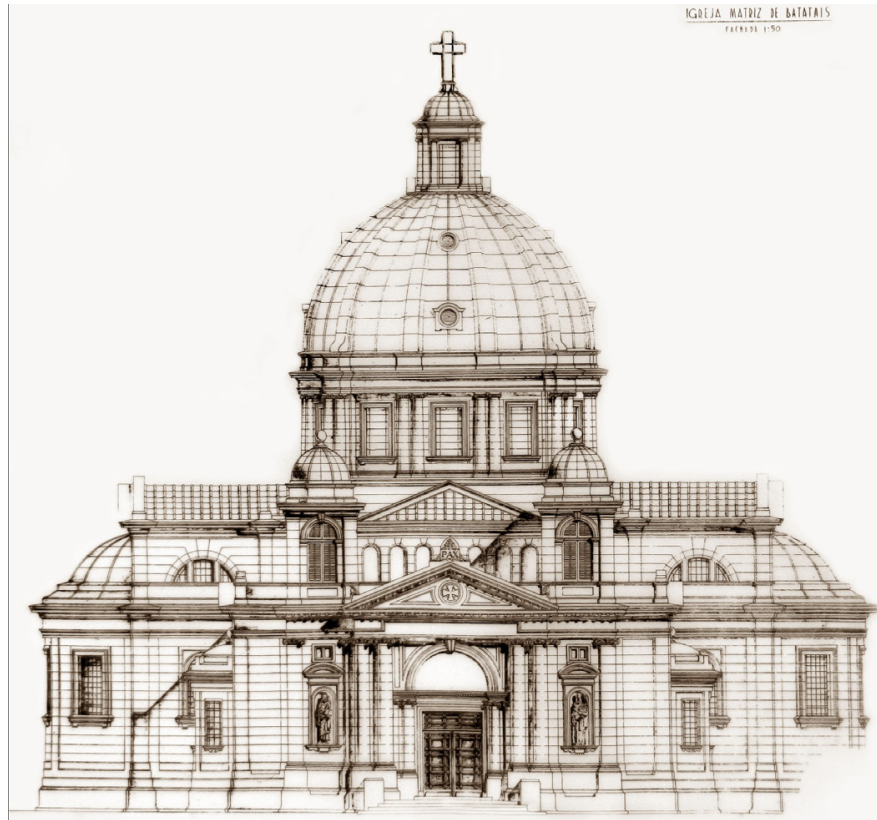

Figura 10 | Projeto para a Igreja Matriz de Batatais modificado por Carlos Zamboni. Fonte: Acervo da Igreja Matriz de Batatais. 


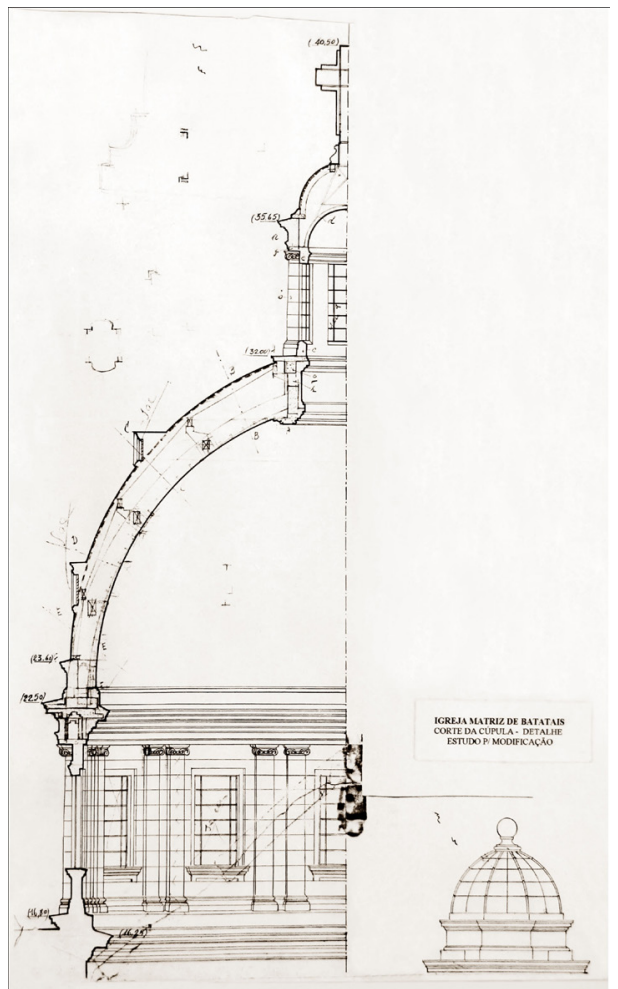


Por motivos pessoais, no final de 1928, Latini se vê obrigado a deixar as obras da Matriz a cargo de Zamboni. Esse último passou então a imprimir seus conhecimentos técnicos na construção da obra. Uma das modificações mais importante empregada pelo engenheiro foi a substituição da cúpula achatada por uma cúpula semiesférica (Figuras 10 e 11), disposta sobre um tambor vazado por vitrais ladeados por colunas jônicas geminadas. Essa intervenção ocasionou um aumento significativo ao edifício e um ajuste técnico-estrutural para o novo peso. Outra interferência no projeto original de Latini feito por Zamboni foi a substituição do frontão em arco rebaixado por arco pleno. Provavelmente, essas mudanças desenvolvidas pelo Engenheiro tenham acontecido em função da interrupção nas obras; a construção aconteceu, em um primeiro momento, entre os anos de 1927 e 1929, quando houve uma paralisação de aproximadamente dez anos. Em 1940, a construção foi retomada até sua conclusão, em 1953.

Acerca dos serviços construtivos, as fundações foram feitas levando em consideração a largura proporcional à carga, devendo o fundo ser apiloado com carga não inferior a 100 $\mathrm{kg}$. Os pilares que sustentam a cúpula passaram por uma prova de resistência do terreno e se, porventura, houvesse a necessidade de estaquear a fundação, seriam utilizadas estacas de aroeira, cujo diâmetro mínimo seria de 0,25 m, sendo uma de suas extremidades imersas numa sapata de 
concreto magro. A primeira sapata foi realizada em concreto simples com $170 \mathrm{~kg}$ de cimento por metro cúbico; as demais, até atingirem o nível do piso, foram feitas de alvenaria de tijolos ou de pedra. A estrutura de alvenaria foi de tijolos simples comuns nas espessuras indicadas no projeto. Os tijolos antes do assente foram molhados. Todas as aberturas foram destacadas na alvenaria para que esta pudesse cobrir o concreto armado. A junção entre o concreto armado e a alvenaria de tijolos foi feita por meio de ferros chumbados na alvenaria com argamassa de cimento e areia. O concreto armado foi utilizado na cobertura do lanternim, na cúpula, na cobertura das torres laterais, no tambor que sustenta a cúpula, vergas e nas colunas dos arcos que separam as naves laterais da central. Em todas as aberturas foram executadas vergas em concreto armado proporcionalmente ao vão livre. O telhado sobre a sacristia, depósitos e demais ambientes foram estruturados aproveitando a madeira de demolição. Os telhados da nave central, dos dois cruzeiros e das quatro capelas foram feitos em peroba, compreendendo ripas, caibros, terças e tesouras. As telhas a serem utilizadas foram as do tipo "grego". Todavia, as cumieras e espigões foram embolsados com argamassa de cal e cimento. As calhas colocadas na Igreja para escoamento das águas da chuva foram feitas em chapas de cobre, constando que a proteção entre calha e platibanda foi feita com rufos em chapa de cobre. Os condutores foram em ferro fundido. A cobertura do lanternim, da 
cúpula, das semicúpulas e das duas torres laterais externas à fachada foi revestida com uma camada de argamassa de cimento comum, cimento branco e areia, segundo o traço 1:1:6, adicionando o impermeabilizante, conforme a dosagem do fabricante. Para que essa camada tivesse a necessária aderência, deveria ser precedida por uma aplicação de mão de cimento e areia, traço 1:1. As lajes sobre as naves centrais, sobre o côro e as platibandas foram impermeabilizadas conforme o mesmo processo. Os forros em madeira foram de tábuas de peroba. Todo o piso da Igreja e da praça à volta da obra foram feitos de concreto de sete centímetros de espessura, com a dosagem de seis sacos de cimento por metro cúbico de superfície acabada. As portas externas foram todas feitas de cabreúva, engradadas com montantes, travessas e almofadas obedecendo às medidas e espessuras dos desenhos. As portas de entrada da igreja foram envernizadas. As portas internas foram construídas conforme as externas, mas em madeira de cedro para as folhas e peroba para os batentes. Toda a madeira usada foi de primeira qualidade, rigorosamente seca, sem fendas, nem defeitos. Os caixilhos de ferro fixos ou basculantes e as portas das capelas foram executados de acordo com o projeto, entretanto todos os caixilhos foram fixados nas paredes com grampos de ferro de tamanho adequado, com forma de "rabo de andorinha", chumbados com cimento e areia. Os caixilhos correspondentes aos altares laterais receberam vitrais de desenhos e cores previamente escolhi- 
dos pela Comissão de Obras e de acordo com a grandiosidade do templo. As partes internas rebocadas receberam três demãos de cal lisa e de cor clara. As portas internas foram pintadas a óleo esmalte de cor clara conforme as existentes na parte já construída. O custo total da obra estipulado (julho de 1943) foi de novecentos e quarenta mil cruzeiros $(\mathrm{Cr} \$ 940.000)^{14}$.

Essa nova e última etapa da construção revela uma transformação da alvenaria antiga na nova Matriz, onde os nichos antigos, as janelas em arcos ogivais e o próprio passado foram sendo preenchidos, fechados para a condição sociocultural desse momento. Latini empregou uma linguagem eclética, de inspiração clássica, mas, de certa maneira, inovadora, com o projeto da cúpula achatada. Já Zamboni resgatou a força da tradição clássica ao modificar o diâmetro do duomo (Figura 12).

A reconstrução, iniciada pela parte dos fundos com a construção da torre do relógio e envolvendo a Igreja velha, esteve sob a direção de Latini. As demais partes, sob a chefia e a nova orientação de Zamboni, sofreram notáveis modificações em relação aos planos iniciais. Latini preocupara-se com maior rigor sobre a qualidade e a quantidade

14. Memorial Descritivo para a Construção da Igreja Matriz de Batatais - Museu Histórico Washington Luís, Batatais - SP. 
dos detalhes e da ornamentação. Seu sucessor promoveu evidente simplificação, o que confere ao restante da obra um aspecto mais sóbrio em relação ao anterior. Zamboni, natural de Brescia, Itália, procura imprimir ao templo de Batatais aspectos similares aos do "Duomo Nuovo" de sua cidade natal, obra em que se baseia para concluir a Matriz de Batatais.

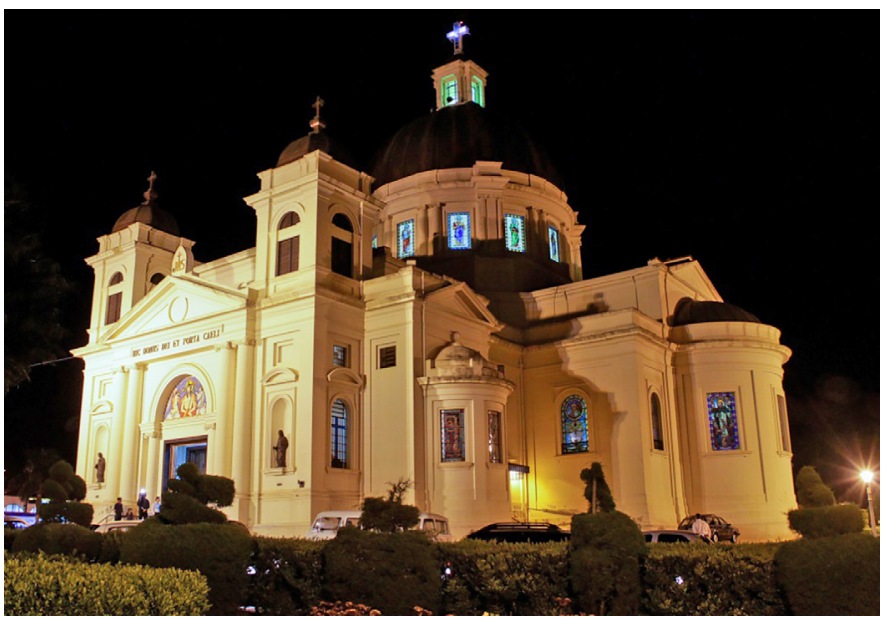

Figura 12 | Igreja Matriz Senhor Bom Jesus da Cana Verde de Batatais, 2013.

Fonte: Acervo da Igreja Matriz de Batatais. 
A catedral de Brescia tem origem no tardo Renascimento. Foi iniciada em 1604 com projeto do arquiteto bresciano Giovan Battista Lantana e concluída em 1825, com uma fachada de evidente gosto neoclássico. $\mathrm{O}$ arquiteto Rodolfo Vantini completou a cúpula em 1825 com projeto de Luigi Cagnola. A cúpula, a terceira maior da Itália, depois da de São Pedro, em Roma, e da de Santa Maria Novella, em Firenze, possui 80 metros de altura, tendo sido reconstruída depois do bombardeamento de 1943 segundo o desenho original de Cagnola. Internamente, é realizada inspirando-se na igreja de Santa Maria di Carignano, em Genova, e se apresenta na forma de uma cruz greca, com profunda abside e oito capelas laterais (LAGO DI GARDA, s/d).

Em relação aos vitrais, na Matriz do Bom Jesus de Cana Verde, parte deles é de autoria de Conrado Sorgenicht FiIho, filho e neto de eminentes vitralistas alemães que se instalaram em São Paulo, por volta de 1875. O conjunto de vitrais constitui-se de um acervo de 48 peças de grandes dimensões. Dessas, destacam-se as que se encontram instaladas em doze janelas da nave da Matriz, onde Conrado colocou os 12 apóstolos, em desenhos de delicada simplicidade, além da representação do Menino Jesus (Figura 13), da Ascensão do Senhor Bom Jesus da Cana Verde e a Assunção de Maria Santíssima nas janelas do presbitério. "Também são de Conrado, assim como o mural, em mosaico de vidro, onde estão o padroeiro Bom Jesus da 
Cana Verde e a mesa de comunhão, também decorada por Conrado" (FERNANDES, 2004, p. 48), procurando harmonizar-se com os trabalhos ali realizados pelo pintor Candido Portinari.

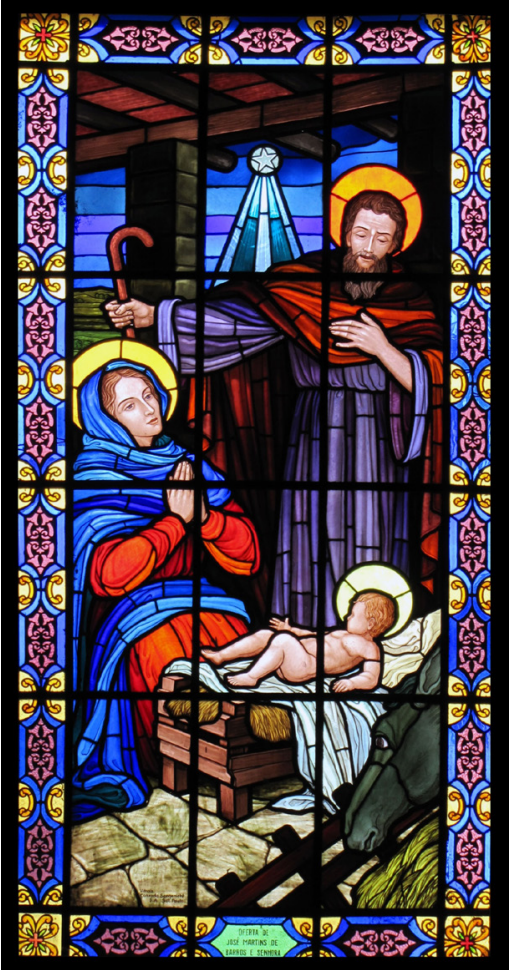

Figura 13 | Menino Jesus de Conrado Sorgenicht Filho. Fonte: Acervo da Igreja Matriz de Batatais. 
Em maio de 1930, novos integrantes assumiram a Comissão que arrecadava fundos para as obras da Igreja. Essa comissão deu continuidade às obras, até então paralisadas, e exerceu seu mandato até a conclusão da Igreja, tendo o Monsenhor Joaquim Alves Ferreira à sua frente. Foi nessa época que o pintor Candido Portinari foi contatado pelo engenheiro-arquiteto da Igreja Matriz de Batatais, Carlos Zamboni, para pintar o templo (FERNANDES, 2004, p. 46).

Candido Torquato Portinari nasceu em Brodowski, cidade vizinha a Batatais, em 29 de dezembro de 1903 e faleceu na cidade do Rio de Janeiro em 6 de fevereiro de 1962. Filho de imigrantes italianos, Portinari conseguiu retratar questões sociais e políticas em suas obras e aproximou-se da arte moderna europeia.

Quando Zamboni e a Comissão procuraram Portinari pela primeira vez, pediram-Ihe que pintasse as estações da Via Sacra de maneira simples, para que todos, ao contemplarem a pintura, compreendessem os últimos passos de Cristo. Nessa época o pintor já havia se filiado ao Partido Comunista e deixara de acreditar em Deus, mas respondeu da seguinte maneira ao pedido: "Não sou católico; não creio, mas compreendo. Muitas das pessoas que mais estimo são católicas e, para elas, a religião é uma coisa importante. Procurarei fazer algo que Ihes agrade" (FERNANDES, 2004, p. 47). 
Em um primeiro momento, foram solicitadas a Candido Portinari apenas quatorze pequenas telas para comporem as estações da Via Sacra, no entanto ele acabou pintando também: o políptico do altar-mor, composto pelo Senhor Bom Jesus da Cana Verde ao centro, seis apóstolos à esquerda, mais seis à direita, o Espírito Santo no alto e anjos na parte inferior (Figura 14); o políptico da Capela de Nossa Senhora Aparecida, com a imagem de Nossa Senhora Aparecida ao centro, três cenas à direita e mais três à esquerda e, no alto, a Igreja Matriz; São Sebastião; O Batismo de Jesus (Figura 15); A Sagrada Família; Fuga para o Egito; A Transfiguração; e, em 14 de março de 1955, foram introduzidas as quatorze telas a óleo, a Via Sacra.

As reconstruções empregadas na Igreja Matriz pelos imigrantes italianos tinham como campo de perspectiva a arquitetura em seu sentido amplo, ou seja, além do conjunto de elementos e contextos que define uma arquitetura, segundo seu tempo, sociedade e cultura, nota-se uma característica singular, peculiar da cultura italiana como berço das artes renascentistas, que é a cidade como traço, desenho, especialmente como arquitetura urbana. 


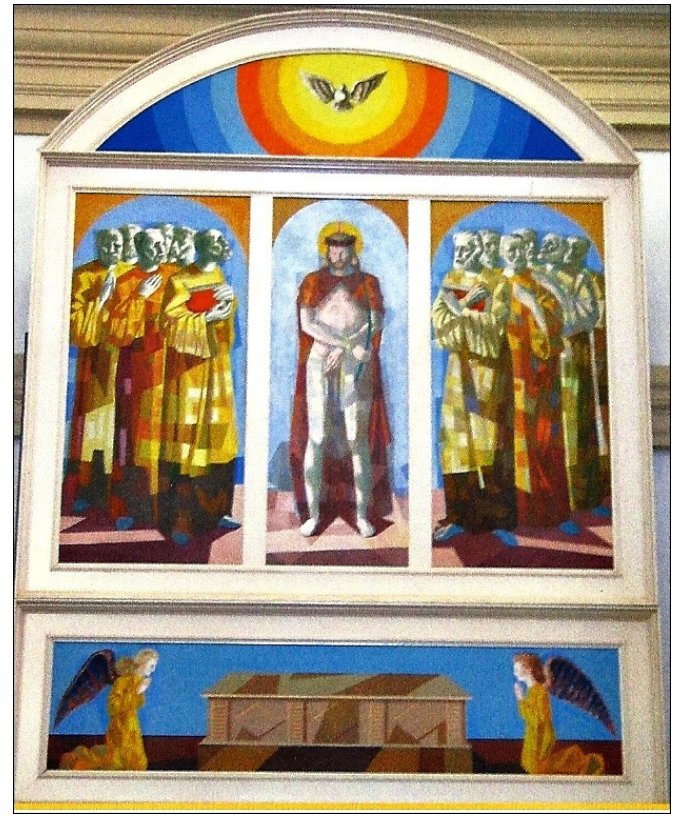

Figura 14 | Políptico do Altar-mor.

Fonte: FERNANDES, 2004, p. 45. 


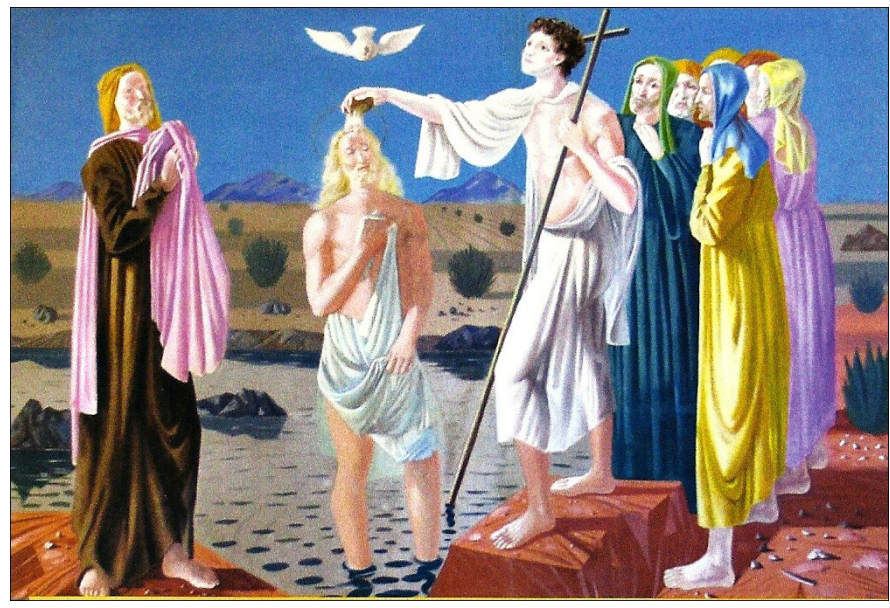

Figura 15 | O Batismo de Cristo.

Fonte: FERNANDES, 2004, p. 46. 
Essa leitura sobre as transformações e os estilos arquitetônicos empregados nas reformas da Igreja Matriz de Batatais, especialmente com a chegada da colônia italiana na cidade, confere a possibilidade de estabelecer uma relação entre a arquitetura Eclética na Europa, segundo as definições de Luciano Patetta, e a manifestação desse estilo no interior do Estado de São Paulo. Segundo Patetta (1987), o que se observa na Europa nesse período é uma mudança estrutural da sociedade decorrente de um novo grupo social que passava a consumir uma "produção em série". Ainda, o estilo em voga revelava um "aparente "caos" devido às diversas correntes estilísticas, contraditórias, mas simultâneas, cujo objetivo era encontrar na Europa do século XIX um estilo próprio. Em meio a essas correntes estilísticas, esse "estilo próprio" estava sendo instituído: o Ecletismo, que se configurava em uma cultura arquitetônica própria da classe dominante (burguesa), que valorizava o conforto, as novidades e o progresso, especialmente quando este último possibilitava numa melhoria de vida. Porém todo esse refinamento "rebaixava a produção artística e arquitetônica ao nível da moda e do gosto" (PATETTA, 1987, p.12-13). As sucessivas reformas que a Igreja Matriz Nosso Senhor Bom Jesus da Cana Verde acabou configurando-se como uma arquitetura religiosa representativa do estilo eclético no interior do Estado de São Paulo. 


\section{Conclusão}

Conforme a tradição herdada do período colonial, a formação de uma nova capela, reivindicada pelos fregueses de uma determinada freguesia, visava ao abrigo espiritual e dava origem a um novo povoado. A construção de um edifício religioso - a capela - representava esse primeiro esforço coletivo da localidade na consolidação de um domínio territorial que poderia dar origem a uma nova localidade urbana. Assim, quando se analisa os processos de construção e reconstrução da Igreja Matriz de Batatais, constata-se que a história da construção de uma matriz é também a história de uma sociedade, significando que o edifício religioso se configura na demonstração de uma realidade socioespacial.

Com a presença dos entrantes mineiros no Sertão do Rio Pardo, a Igreja Matriz de Batatais foi construída na forma vernacular derivada do ideário colonial; com a imigração italiana, que implicou na presença de profissionais formados em academias europeias de arquitetura, o mesmo edifício expressou linguagens eruditas: o neogótico e o ecletismo. Desse modo, o que se depreende dessa conjuntura é que a reforma do edifício religioso representou uma nova ordem social, cultural e econômica, fruto da mudança estrutural da sociedade em decorrência de um novo grupo social que ganhava destaque no cenário citadino. 
Reinaugurada em 14 de março de 1953, a Igreja Matriz do Nosso Senhor Bom Jesus da Cana Verde de Batatais trazia em seu arcabouço artístico e técnico, tal qual se apresenta nos dias de hoje, um ideário que ia além de suas estruturas; por conseguinte, nesse dia as portas da Matriz se abriram não como uma igreja, antes como um salão de exposição de arte. É nessa perspectiva que se pode pontuar esse diálogo, ou seja, entender a história da construção desse edifício como parte da história da arte do nordeste do interior paulista. Assim, têm-se um edifício, dois momentos históricos e três obras, contextos que revelam técnicas, circunstâncias e conhecimentos adotados na edificação da Igreja Matriz do Nosso Senhor Bom Jesus da Cana Verde.

A construção e as reconstruções desenvolvidas tanto pelos mineiros como pelos italianos conceberam e expressaram esses processos técnicos e arquitetônicos do edifício sob parâmetros de uma perspectiva ampla do conceito de arquitetura, ou seja, associaram a mudança estrutural da sociedade diretamente ao problema da organização do homem no espaço, particularmente no espaço urbano.

Trata-se de um processo representativo da ocupação do território paulista, pois, conforme as circunstâncias foram sendo (re)desenhadas, as camadas construtivas foram sendo expostas, juntamente com seus valores intrínsecos, o que na maior parte pode ser considerado fator primordial 
para a preservação. Nesse sentido, além dos valores afetivos, sociais e culturais que a Igreja Matriz de Batatais possui, pode-se considerar, para a relevância da sua história, a memória e o valor tecnológico que a sua construção circunscreve.

\section{Referências}

BRIOSCHI, Lucila Reis. Criando história: paulistas e mineiros no nordeste de São Paulo (1725-1835). 1995. 266 f. Tese (Doutorado em Sociologia) - Faculdade de Filosofia, Letras e Ciências Humanas da Universidade de São Paulo, São Paulo, 1995.

CHIACHIRI FILHO, José. Do Sertão do rio Pardo à Vila Franca do Imperador. Ribeirão Preto: Ribeirão Gráfica e Editora Ltda., 1986.

DERNTL, Maria Fernanda. Método e arte: criação urbana e organização territorial na capitania de São Paulo (1765-1811). 2010. 225 f. Tese (Doutorado em História e Fundamentos da Arquitetura e do Urbanismo) - Faculdade de Arquitetura e Urbanismo da Universidade de São Paulo, São Paulo, 2010.

DUTRA, Maria Stella Teixeira Fernandes. A arquitetura de Batatais, 1880 a 1930. Dissertação (Mestrado em História) - Departamento de História do Instituto de Filosofia e Ciências Humanas da Universidade Estadual de Campinas, Campinas, 1993.

FERNANDES, José Mauro Marinheiro. Batatais: a cidade dos mais belos jardins. São Paulo: Noovha América, 2004.

FREITAS, Sônia Maria de. E chegaram os imigrantes... (o café e a imigração em São Paulo). São Paulo: Edição da Autora, 1999.

GAZETA DE BATATAIS. O gosto artístico do que se fez e do que si fará. Batatais, 25/02/1926, p. s/n, 1926a.

. Carta ao Leitor. Batatais, 01/03/1926, p. s/n, 1926b. . Carta ao Leitor. Batatais, 21/01/1927, p. s/n, 1927a. Engenheiro Architecto. Batatais, 04/09/1927, p. s/n, 1927b. 
GHIRARDELLO, Nilson. A formação dos patrimônios religiosos no processo de expansão urbana paulista (1850 - 1900). São Paulo: Ed. UNESP, 2010.

BATATAIS ONLINE. Grande colônia italiana. Disponível em: http:// batataisonline. com.br/batatais/colônias. Acesso em: 20/06/2013.

LAGO DI GARDA MAGAZINE. s/d. Disponível em: http://www.lagodigardamagazine.com/ brescia.aspx. Acesso em: 04/03/2016.

LEITE, Mario. Paulistas e mineiros, plantadores de cidades. São Paulo: Edart, 1961

MARX, Murillo de Azevedo. Cidade brasileira. São Paulo: Melhoramentos Edusp, 1980.

PATETTA, Luigi. Considerações sobre o Ecletismo na Europa. In: A. FABRIS (org.), Ecletismo na Arquitetura Brasileira. São Paulo: Editora da Universidade de São Paulo, 1987.

PICCINATO JUNIOR, Dirceu. Terra urbana, patrimônio fundiário: uma análise histórica da apropriação do solo na configuração do urbano no nordeste paulista (1800 - 1930). Dissertação de Mestrado. Pontifícia Universidade Católica de Campinas - PUC-Campinas, 2012. $341 \mathrm{p}$.

SANTOS, Maria das Graças Vieira Proença dos. História da Arte. São Paulo: Editora Ática, 2007.

TAGOMORI, Andreia Tiemi; CAVALLARO, Fernanda. 2011. Construção em tijolo de adobe. Disponível em: http://www.usp.br/fau/cursos/ graduacao/arqurbanismo/disciplinas/ aut0221/TrabalhosFinais2011/ ConstrucaoemTijolodeAdobe.pdf. Acesso em: 20/03/2016. 